\title{
HILFSBUCH
}

ZLR

\section{GESCHICHTE DER PHILOSOPHIE}

\author{
SEIT KANT
}

VON

DR. RICHARD FALCKENBERG,

ORD. PROFESSOR DER PHILOSOPHIE IN FRLANGEN.

LEIPZIG

VERLAG VON VEIT \& COMP.

1899 

MEINEM LIEBEN FREUNDE

\section{KARL NIEMANN}

IN BERLIN

IN TREUER ANHÄNGLICHKEIT

GEWIDMET 
